\title{
The Work-Life Conflict and Satisfaction with Life: Correlates and the Mediating Role of the Work-Family Conflict
}

\author{
Ana-Maria Cazan ${ }^{1}$, Camelia Truţă $^{1} *$ \& Mariela Pavalache-Ilie ${ }^{1}$ \\ ${ }^{1}$ Department of Psychology, Education and Teacher Training, Transilvania University of Brasov, Romania.
}

Received 2.05.2019; Received revised 22.05.2019; Accepted 29.06.2019

Available online 30.06.2019

\begin{abstract}
The permeable boundary between family life and professional life allows interferences between them which could lead to either positive or negative consequences in both plans of the employees' lives. Our paper aims to analyse the relationships between the work-family conflict, organizational attachment, positive and negative affectivity, work satisfaction and life satisfaction and last but not least, well-being. The sample consisted of 245 employees. The main hypothesis highlights the mediating role of the work-family conflict in the relationship between affectivity, workplace attachment and job satisfaction and satisfaction with life. Future research could focus on the environmental factors mediating the relationships between life and job satisfaction and on their interaction with the dispositional factors.
\end{abstract}

Keywords: job satisfaction, satisfaction with life, well-being, work-family conflict.

Address of correspondence: Camelia Truţă, Education and Teacher Training, Transilvania University of Brasov, Bl. Eroilor 29, Romania.

E-mail: camitruta@unitbv.ro

\section{Introduction}

Considering the organization as an open system, its main outcome at the level of human resources is the behaviour of the employees seen as a blend of gained competence and knowledge, job satisfaction, stress and emotions, attachment and well-being (McShane \& Von Glinow, 2012). Although work greatly contributes to the existential fulfilment, its universe is frequently interfered with other aspects of personal life that are also essential for psychological well-being and happiness. The permeable boundary between family life and professional life allows interferences between them (Zedeck, 1992) which could lead to either positive or negative consequences in both plans of employees' life (Grzywacz \& Marks, 2000; Roehling, Moen, \& Batt, 2003). Approaching the work-life conflict from a unilateral and falsely dichotomized perspective is a general tendency, as the experience of 'work' is considered to be negative (due, mainly, to long working hours) (Eikhof, Warhurst, \& Haunschild, 2007). Still, a full understanding of the process is only possible from a dual perspective, that of the interference of work related demands with home responsibilities (Work-life Conflict) and the impediment of family responsibilities on work activities (Life-work Conflict) (Netemeyer, Boles, \& McMurrian, 1996; Carlson \& Kacmar, 2000). The perspective should even be enlarged as individuals play multiple roles in life, beside the professional and family ones and gain a broader interest in sport, leisure or community roles (Hall, Kossek, Briscoe, Pichler, \& Lee, 2013). The degree of engagement and satisfaction, in equal measure, with the work and non-work roles is conceptualized as the Work-Life Balance (Greenhaus \& Powell, 2003).

The work-life balance is threatened by several factors, among which the competition on the labour market is one of the strongest, especially for women (Amstad, Meier, Fasel, Elfering, \& Semmer, 2011). Romania, for example, is one of the European countries with the highest gap between men and women in term of employment (only $56.1 \%$ of women are active on the labour market in as compared to $74.6 \%$ of men, according to The Global gender gap report) (World Economic Forum, 2018).

The long working hours or time-based pressure (Greenhaus \& Beutell, 1985) also accentuate the work life interferences, since work overload and role conflict are often identified as predictors of the work-life conflict (Carlson \& Kacmar, 2000). Prolonged working hours are determined not only by increased workload, but also by the new communication technologies that have led to $24 / 7$ workplaces (Berkowsky, 2013; Golden, 2013). The rapid changes in the nature of work (Chandra, 2012), job 
ambiguity, job overload are strain-based pressures (Greenhaus \& Beutell, 1985) are considered to be stressors for employees.

One of the negative consequences of the work-life spill-over is the inter-role conflict, a topic of old interest in IO Psychology (Kahn, Wolfe, Quinn, Snoek, \& Rosenthal, 1964; Greenhaus \& Beutell, 1985). Work/ non-work conflict appears when participation in one of the roles associated with a domain is hindered or negatively affected by assuming one or several roles in the other domain (Greenhaus \& Beutell, 1985). A second outcome variable is the turnover intention of the employees. While in their meta-analysis Allen, Herst, Bruck, and Sutton (2000) report a weighted mean correlation of .29 between WLC and intentions to leave organizations, a previous study of Greenhaus, Collins, Singh, and Parasuraman (1997) show that WLC correlate with actual turnover but the association is substantially lower (.14).

\section{Work-life conflict and job satisfaction}

Job satisfaction is the outcome variable most frequently associated with the work-life conflict (Allen, Herst, Bruck, \& Sutton, 2000). Previous studies show that both work-life conflict and life-work conflict are negatively associated with employees' satisfaction (Netemeyer et al., 1996), with a mean correlation of -.24 (Allen et al., 2000) when job satisfaction is measured as a global evaluation. Strain-based work and interference with family commitment was also found to lead to decreased job satisfaction, across multiple samples (Spector et al., 2007) or across generational groups (Chung, Kamri, \& Mathew, 2018).

The relation between work-life conflict and life satisfaction is also frequently investigated, as the latter is considered to be the one non-work aspect of life most strongly associated with work-family interferences. Research has demonstrated that the work-life balance is associated with increased overall life satisfaction (Allen et al., 2000; Carlson et al., 2006). Michaels and colleagues (1988) suggest that lack of engagement and involvement in life's major roles, such as work or family roles may have a negative impact on life satisfaction.

\section{Work-life conflict and organizational attachment}

Organizational commitment has also been studied in relation to the work-life conflict and both Netemeyer and colleagues (1996) and Allen and colleagues (2000) found that the correlation is negative. More specifically, the work-life conflict is negatively associated with affective commitment, positively correlated with continuance commitment, but not related to normative commitment (Lyness \& Thompson, 1997). The weighted mean correlation between the work-life conflict and affective commitment was -.23 (Allen et al., 2000), but the correlation varies substantially when participants in the studies come from homogenous samples (employees from the same organization or occupation) or from heterogeneous ones (employees from different organizations or occupations).

\section{Work-life conflict and well-beingt}

The work-family life conflict was linked to the employees' well-being, due to the fact that it is one of the most important predictors of well-being, even after adjusting for job characteristics (Neto, Chambel, \& Carvalho, 2018). However, the majority of studies focused on the effect of the work-to-life conflict on psychological distress as a result of workplace demands interfering with personal/family responsibilities (Minnotte, Gravelle, \& Minnotte, 2013). In an extensive integrative review on antecedents and consequences of work-life balance, Sirgy and Lee (2018) point out that conflict between work and family roles is associated with symptoms of low mental well-being and stress-related outcomes, such as emotional exhaustion, anxiety and depression, affective parental distress, irritability and hostility. Much of the research on the work-life conflict has shown a consistent pattern of decrease in job satisfaction, organizational commitment, job performance, life satisfaction, marital satisfaction and emotional well-being as the work-life conflict increases (Sirgy \& Lee, 2018; Allen et al., 2000). Still, there are fewer studies on the impact of work-life conflict on psychological well-being, as an overall positive evaluation of and positive functioning in the relationships with the self, the others and the environment (Ryff, 1989).

\section{Research questions and hypotheses}

On the basis of previous research, our paper aims to analyse the relationships between work-family conflict, organizational attachment, positive and negative affectivity, work satisfaction and satisfaction with life and well-being. Several demographical characteristics were taken into account, namely gender and number of children and an organizational aspect, the type of organization (public versus private). The main hypotheses of our study are the following:

H1. Job satisfaction and work-family conflict are associated, thus we expect participants with a higher job satisfaction to have lower levels of work-family conflict.

H2. The work-family conflict mediates the relationship between affectivity, workplace attachment, job satisfaction and satisfaction with life.

\section{Method}

\section{Participants and Procedure}

The participants were 245 employees, 50 male and 193 female and two participants who did not want to declare their gender. The mean age was 37.61 years $(\mathrm{SD}=9.82$, $\mathrm{Xmin}=19, \mathrm{X} \max =64$ ). Our factual data questionnaire also revealed important aspects regarding the participants' status on the labour market and their personal characteristics:

- The seniority: $\mathrm{M}=15.75, \mathrm{SD}=9.70, \mathrm{Xmin}=1$, $\mathrm{Xmax}=40$;

- The seniority at the latest job: $\mathrm{M}=8.91, \mathrm{SD}=8.18$, $\mathrm{Xmin}=1, \mathrm{Xmax}=40$;

- The educational level: 29 participants $(11.8 \%)$ graduated from high school, 88 participants $(35.9 \%)$ from university and $125(51 \%)$ had post-university studies. Three participants (1.2\%) did not answer this question;

- The position in the organization: 181 participants $(73.9 \%)$ were part of staff or line in their organizations, while $61(24.9 \%)$ were executives.

- The marital status showed the following distribution: 156 participants $(63.7 \%)$ were married, 64 participants $(26.1 \%)$ were not married but involved in a stable relationship, 15 participants $(6.1 \%)$ were single, seven participants $(2.9 \%)$ were in a different situation and three participants did not declare anything about their marital status.

- The type of the organization: 122 participants $(49.8 \%)$ worked in a public organization while 120 
participants $(49 \%)$ in a private organization. There were also three missing data;

- The number of children: 111 participants (45.3\%) did not have children, 89 participants $(36.3 \%)$ had only one child, 37 participants $(15.1 \%)$ had two children, six participants $(2.4 \%)$ had three children and two participants did not declare anything about this aspect.

For this study, we used a correlational design, using an online administered questionnaire with Google form. The invitation to participate in the study was posted for nearly three months on a social media platform or sent by e-mail. Informed consent was obtained from all participants included in the study.

\section{Instruments}

We used the following scales:

1) The Workplace Attachment Scale (Rioux, 2006) - a unidimensional scale that contains six items evaluating attachment to specific places of work. The six items are measured on a 5-point Likert scale. The Cronbach's Alfa coefficient revealed a high reliability for the Romanian version of the instrument used in this study, .90

2) The Satisfaction with Life Scale (Diener, Emmons, Larsen, \& Griffin, 1985) used to measure subjective wellbeing. The scale includes five items rated on a 7-point Likert scale (from $1=$ strongly disagree to $7=$ strongly agree). The Satisfaction with Life Scale was developed to assess the respondents' satisfaction with 'life as a whole', higher scores indicate greater life satisfaction. Previous studies using the Romanian version of SWLS reported good psychometric properties, the Cronbach's Alfa coefficient obtained for the entire scale being .90 (Cazan, 2014).

3) The Psychological Well-being scales (Ryff \& Keyes, 1995) include six scales: Self-Acceptance, Environmental mastery, Positive relations with others, Personal growth, Purpose in life and Autonomy. Each scale consists of three items; on a scale from 1 to 5 , respondents indicated whether they agreed or disagreed strongly, moderately, or slightly that an item described how they thought and felt. Higher scores on each scale reflect the presence of more positive appraisals. Consistent with previous studies (Keyes, Ryff, \& Schmotkin, 2002; Ryff \& Keyes, 1995), our study exhibited lower to modest internal (alpha) reliabilities for the six scales, therefore we decided to use the summed scores as an indicator of well-being, with higher score indicating greater well-being. The Cronbach's alpha coefficient for the entire scale was .73 , showing an acceptable reliability.

4) Positive and Negative Affect Schedule - PANAS (Watson, Clark, \& Tellegen, 1988) comprises 20 items organised in two mood scales, one measuring positive affectivity (10 items, with a Cronbach's Alfa coefficient of $.78)$ and the other measuring negative affectivity (10 items, with a Cronbach's Alfa coefficient of .85). Each item is rated on a 5-point scale (ranging from $1=$ Very slightly or not at all to $5=$ Extremely) to indicate the extent to which the respondent has felt this way in the indicated time frame, the last week.

5) The Job Satisfaction Survey (Spector, 1985) is an 18 items questionnaire used to evaluate the overall job satisfaction. The higher scores indicate a higher satisfaction and the Cronbach's alpha coefficient is .83.

6) The Work-family conflict scale (Carlson, Kacmar, \& Williams, 2000) is an 18 items scale measuring the work to family direction of conflict ( 9 items) and the family to work direction of conflict (9 items). Work interference to family include three dimensions (having three items): Time-based work interference with family $(\alpha=.89)$, Strain-based work interference with family $(\alpha=.57)$, Behavior-based work interference with family $(\alpha=.85)$. Family interference with work also includes three dimensions, but formulated in the other direction: Timebased family interference with work $(\alpha=.89)$, Strain-based family interference with work $(\alpha=.81)$, Behavior-based family interference with work $(\alpha=.89)$. Higher scores for each dimension show a greater interference and conflict between the two aspects, work and family. For the entire scale, Cronbach's alpha was .90.

\section{Results}

The obtained results showed that there were negative correlations between the work-family conflict and job and life satisfaction (Table 1). The results showed negative significant associations between the work-family conflict dimensions and all other variables, except affectivity. There were no associations with positive affectivity, but there were positive and significant associations with negative affectivity.

Participants experiencing higher levels of work-family conflict had lower levels of satisfaction, both with life and with their work, they also had a higher level of negative affectivity and a lower level of well-being. The results are similar for the work interference with family and for the family interference with work dimensions.

The correlations between the other measured variables were as expected (Table 1). Psychological well-being correlated positively with satisfaction with life, job satisfaction and positive affectivity and negatively with negative affectivity. The highest correlation coefficient was obtained between satisfaction with life and job satisfaction, showing that job satisfaction could be an indicator of overall satisfaction. Workplace attachment was also positively associated with job satisfaction. The weakest correlations were found for positive affectivity and as expected, the strongest correlation was obtained for the association with well-being.

The second tested hypothesis was that the work-family conflict mediates the relationship between affectivity, workplace attachment and job satisfaction and satisfaction with life.

The goodness-of-fit indices for the tested model showed a good fit (Table 2). According to Hu \& Bentler (1999) and Kline (2011), the goodness-of-fit criteria used in the current study acknowledged the potential for $\mathrm{d}$ excellent fit $(\chi 2 / \mathrm{df}$ ratio $<2$, CFI and TLI $>.95$, SRMR $<.08$, RMSEA $<.06)$. Mahalanobis distance showed no evidence of multivariate outliers.

The significance of the mediating effect of the workfamily conflict was tested using the Bootstrap estimation procedure in AMOS. The standardized path coefficients and the standardized indirect effect and its associated $95 \%$ confidence levels of significance are displayed in Table 11. The indirect effects, although small, are statistically significant for two variables, job satisfaction and negative affectivity (Cheung \& Lau, 2008; Iacobucci, 2008). 
Table 1. Pearson correlation coefficients between study variables

\begin{tabular}{|c|c|c|c|c|c|c|c|c|c|c|c|c|c|c|}
\hline & $(1)$ & (2) & (3) & (4) & $(5)$ & (6) & (7) & (8) & (9) & $(10)$ & $(11)$ & (12) & (13) & $(14)$ \\
\hline Psychological well-being (1) & 1 & & & & & & & & & & & & & \\
\hline Satisfaction with life (2) & $.56^{* *}$ & 1 & & & & & & & & & & & & \\
\hline Job satisfaction (3) & $.31 * *$ & $.39 * *$ & 1 & & & & & & & & & & & \\
\hline Workplace attachment (4) & $.25 * *$ & $.42 * *$ & $.40 * *$ & 1 & & & & & & & & & & \\
\hline Positive affectivity (5) & $.38 * *$ & $.23 * *$ & $.14 *$ & $.18^{* *}$ & 1 & & & & & & & & & \\
\hline Negative affectivity (6) & $-.36^{* *}$ & $-.36 * *$ & $-.25 * *$ & $.218 * *$ & -.02 & 1 & & & & & & & & \\
\hline Time-based work interference with family (7) & -.11 & $-.26 * *$ & $-.19 * *$ & $-.21 * *$ & $.13 *$ & $.16^{* *}$ & & & & & & & & \\
\hline Time-based family interference with work (8) & $-.21 * *$ & $-.21 * *$ & $-.16^{* *}$ & -.10 & .05 & $.19 * *$ & $.47 * *$ & & & & & & & \\
\hline Strain-based work interference with family (9) & $-.25^{* *}$ & $-.37 * *$ & $-.37 * *$ & $-.31 * *$ & .10 & $.34 * *$ & $.64 * *$ & $.46 * *$ & 1 & & & & & \\
\hline Strain-based family interference with work (10) & $-.24 * *$ & $-.17 * *$ & -.06 & -.08 & $-.13 *$ & $.25 * *$ & .06 & $.34 * *$ & $.15^{*}$ & 1 & & & & \\
\hline Behavior-based work interference with family (11) & $-.22 * *$ & $-.32 * *$ & $-.21 * *$ & $-.19 * *$ & .045 & $.30 * *$ & $.43 * *$ & $.37 * *$ & $.43 * *$ & $.30 * *$ & & & & \\
\hline Behavior-based family interference with work (12) & $-.22 * *$ & $-.32 * *$ & $-.21 * *$ & $-.25 * *$ & .050 & $.28 * *$ & $.33 * *$ & $.24 * *$ & $.36^{* *}$ & $.21 * *$ & 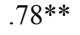 & & & \\
\hline Work interference to family (13) & $-.24 * *$ & $-.39 * *$ & $-.318^{* *}$ & $-.29 * *$ & .113 & $.33 * *$ & $.84 * *$ & $.55^{* *}$ & $.84 * *$ & $.20 * *$ & $.75^{* *}$ & .66 & & \\
\hline Family interference with work (14) & $-.31 * *$ & $-.34 * *$ & $-.21 * *$ & $-.22 * *$ & -.027 & $.34 * *$ & $.40 * *$ & $.68 * *$ & $.46^{* *}$ & $.69 * *$ & $.72 * *$ & .76 & & \\
\hline Work-life conflict total (15) & $-.30 * *$ & $-.40 * *$ & $-.30 * *$ & $-.29 * *$ & 06 & $.37 * *$ & $.73 * *$ & $.65^{* *}$ & $.75 * *$ & $.45^{* *}$ & $.81^{* *}$ & $.73^{* *}$ & $.93 * *$ & $.86^{* *}$ \\
\hline
\end{tabular}

Work-life conflict total (15)

$$
\text { Notes. } * \mathrm{p}<.05, * * \mathrm{p}<.01, \mathrm{~N}=245 \text {. }
$$

Table 2. The Goodness-of-fit measures for the mediating effect of computer anxiety

\begin{tabular}{llllll}
\hline$\chi^{2} / d f$ & GFI & $C F I$ & AIC & SRMR & RMSEA $(90 \%$ CI) \\
\hline .008 & 1 & 1 & 40.08 & .002 & $.001-.050$ \\
\hline
\end{tabular}

Notes. GFI: Goodness-of-Fit Index, CFI: Comparative Fit Index, AIC: Akaike Information Criterion, SRMR: Standardized Root Mean Square Residual, RMSEA: Root Mean Square Error of Approximation, 90\% CI: 90\% confidence interval for RMSEA.

Table 3. Direct, indirect and total effects (Standardized estimates) for the structural model

\begin{tabular}{lllll}
\hline Variables & Work-family conflict & \multicolumn{2}{l}{ Satisfaction with life } & \\
& Direct/Total & Direct & Indirect & Total \\
& & & & \\
\hline Workplace attachment & $-.14^{* *}$ & $.19^{* *}$ & .03 & $.22^{* *}$ \\
Job satisfaction & $-.21^{* *}$ & $.22^{* *}$ & $.04^{*}$ & $.26^{* *}$ \\
Positive affectivity & $.11^{* *}$ & $.18^{* *}$ & -.02 & $.16^{* *}$ \\
Negative affectivity & $.27^{* *}$ & $-.16^{* *}$ & $-.06^{* *}$ & $-.22^{* *}$ \\
Work-family conflict & - & $-.21^{* *}$ & & $-.21^{* *}$ \\
\hline
\end{tabular}

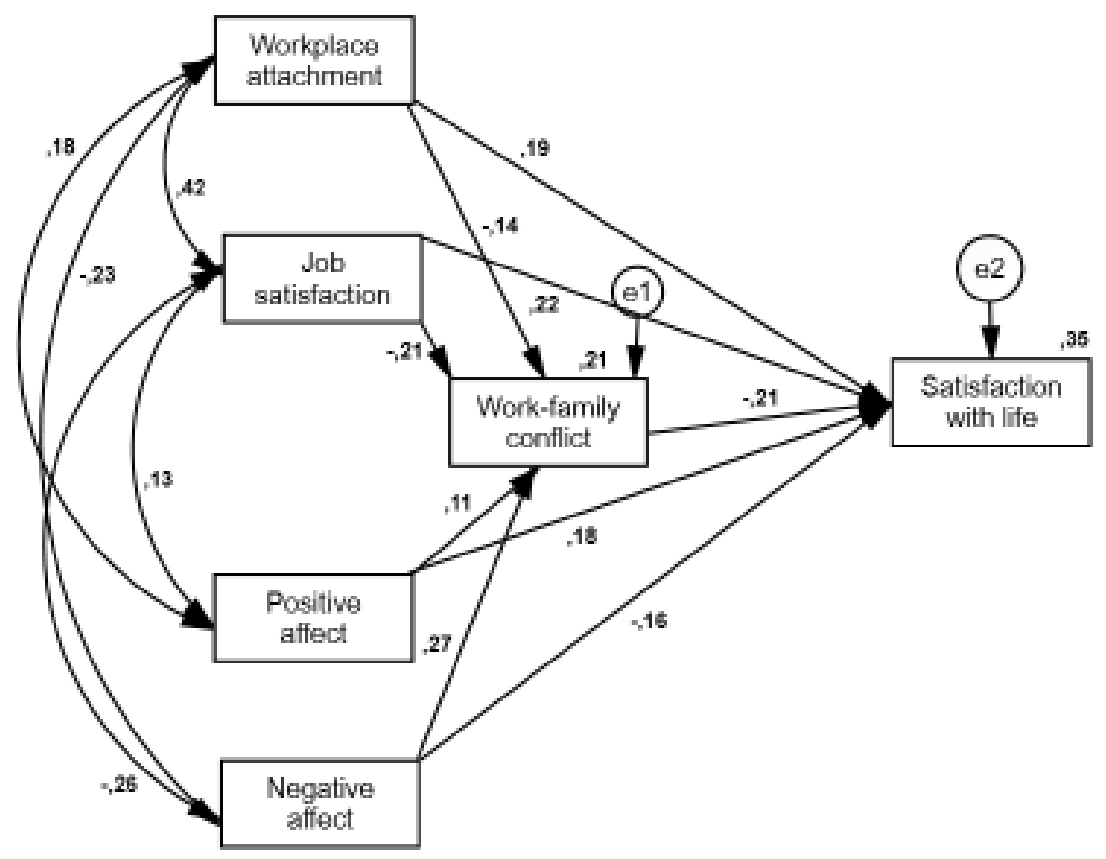

Figure 1. Scheme of color manipulation of the pictures 
Testing the individual paths presented in Figure 1 and analyzing the significance levels of the indirect effects (Table 3), it can be concluded that the results sustain the mediation hypothesis. The results showed that the association between job satisfaction and satisfaction with life is mediated by the work-family conflict. While the direct effect of positive affectivity on satisfaction with life is slightly stronger than the effect of the direct effect of negative affectivity, the path analysis showed that the effect of the negative affectivity on the satisfaction with life is also amplified by the work-family conflict. Workplace attachment has a significant positive effect on satisfaction with life, a high attachment predicts a high satisfaction. The indirect effect of attachment is not significant. Job satisfaction and workplace attachment both had a significant negative effect on the work-family conflict, showing that a high level of satisfaction and attachment predict a lower level of conflict, thus a good balance between professional and personal life which, in turn predicts a higher level of satisfaction with life.

Differences by the type of organization and by gender were also tested. The results showed that there were no significant differences between the employees working in different types of organization regarding the work-family conflict dimensions, but that there were differences for the job satisfaction (t224.78 4.04, $\mathrm{p}<.001, \mathrm{~d}$ Cohen $=.53)$ and the workplace attachment ( $\mathrm{t} 224.783 .23, \mathrm{p}<.001$, d Cohen $=.42$ ). Thus, the employees from private organizations ( $\mathrm{M}$ $=3.46, \mathrm{SD}=.65)$ had higher level of satisfaction with their jobs than those working in public organizations $(\mathrm{M}=3.15$, $\mathrm{SD}=.50)$; and, on the other hand, the employees from private organizations expressed a lower workplace attachment $(\mathrm{M}=3.12, \mathrm{SD}=1.00)$ than the employees from public organizations $(\mathrm{M}=3.55, \mathrm{SD}=.1 .04)$. For the workplace attachment the differences remained significant even when seniority at the latest job was controlled, $\mathrm{F}(1$, $243)=5.56, p=.019, \xi 2=.02$. The same significant differences were obtained for the job satisfaction, with the seniority at the latest job under control, $\mathrm{F}(1,243)=10.37$, $\mathrm{p}=.001, \xi 2=.04$. Concerning gender, the results showed that there were no gender differences for the work-family conflict dimensions or for job satisfaction, however women $(\mathrm{M}=3.40, \mathrm{SD}=1.04)$ had a higher workplace attachment than men $(\mathrm{M}=3.02, \mathrm{SD}=1.05): \mathrm{t} 241=2.34, \mathrm{p}<.05, \mathrm{~d}$ Cohen $=.36$.

The variables number of children or marital status did not introduce any difference in terms of work-family conflict. There were no differences between participants who had one or more children and those without children, or between married or not married participants.

\section{Discussion}

Job satisfaction is found to be negatively correlated with work to family interference and with family to work interference. The results are convergent with other results reported in the literature; previous researches examined a negative relationship between job satisfaction and workfamily interference, as a result of long working hours and a highly demanding job (Cabrita \& Perista, 2006; Janasz \& Behson, 2007; Gao, Shi, Niu, \& Wang, 2013). Burke $(1997,2000)$ found that job satisfaction and job commitment were associated with the organizational support of work-family balance. The employees who perceived a high organizational commitment tended to have higher levels of job satisfaction and family satisfaction, generally higher life satisfaction and more positive emotions and wellbeing (Burke, 2000).

The results regarding the correlations between satisfaction with life, job satisfaction, workplace attachment, well-being and affectivity were similar to those reported in the literature. The correlations between wellbeing, satisfaction with life and affectivity suggest that subjective well-being includes two components: the cognitive component, which determines the perception of life satisfaction (Dorahy, Lewis, Schumaker, AkuamoahBoateng, Duze, \& Sibiya, 2000) and the emotional component which includes our positive and negative emotions (Rask, Astedt-Kurki, \& Laippala, 2002; Connolly, \& Viswesvaran, 2000). Workplace attachment is highly correlated with job satisfaction, being a predictor of the later variable, as previous studies have shown (Rioux \& Pignault, 2013).

The results revealed that there were no differences in terms of work-family conflict between the participants from public and private organizations. Although the employees from private organizations were more satisfied with their jobs, they expressed lower workplace attachment than the employees from public organisations. The differences between public and private organizations are very controversial in the literature. Boyne's study (2002) suggests that public management is characterized by more bureaucracy, a stronger desire to promote public welfare and lower organizational commitment. DeSantis and Durst (1996) found that monetary reward and personal characteristics such as educational level are strongly related to job satisfaction in private employees while job significance and organizational climate is stronger for public employees. Buelens and Broeck (2007) suggest that public employees have higher levels of work satisfaction because they experience less work-family conflict, they have fewer working hours, present less willingness to exert considerable effort on behalf of the organization and are less motivated by extrinsic rewards when compared to private sector employees. The divergent results reported in the literature could be explained by the multidimensionality of the work satisfaction construct. Wang and his colleagues (2012) explain that public employees are more satisfied than private sector workers in relation to job security and the non-competitive and more supportive environment in the workplace, while private employees report higher levels of satisfaction with reward and possibility of growth, flexibility in the work process and autonomy. Regarding the differences for the workplace attachment, the results are also controversial. In a metaanalysis study, Boyne (2002) showed that while some studies found that the public sector had a lower commitment that the public sector, other studies found no difference. The lower levels of public sector commitment were however caused by the inflexible personnel procedures and the limited link between job performance and rewards (Markovits, Davis, Fay, \& Van Dick, 2010).

Although there were no gender differences, our conclusions could be influenced by the small number of male participants in the study. A recent sociological research showed that men and women experience different levels of work-family conflict depending on the working time. Thus, individuals that are frequently experiencing non-standard working hours have higher levels of conflict than individuals working under normal employment conditions. Other interesting findings reported in the cited paper were the following: higher levels of job security apparently reduced conflict for both men and women and 
freedom and flexibility in work organisation triggers workfamily conflict for men, while the same aspects reduce conflict for women (Hofacker \& Konig, 2012). Byron (2005) suggested that different factors may influence levels of work-family conflict in men and women, however, these differences are not extensively studied and the gender differences are relatively small. Different results are reported by Cinamon (2006), concluding that female students perceived significantly higher levels of workfamily conflict as compared to male students.

The results sustain the mediation hypothesis. The relationships between work-family conflict, job satisfaction, life satisfaction and affectivity have been the subject of recent research, although this issue was also extensively studied in the past. In a meta-analysis study, Kossek and Ozeki (1998) presented evidence for the associations between these variables. There are studies adopting a dispositional perspective and showing that work-family conflict moderates the association between job satisfaction and life satisfaction (Qu \& Zhao, 2012). Other studies also include aspects such as the coping style, problem-solving coping was found to partially mediate the negative relationship between the work-family conflict and life

\section{Limitations and Future research directions}

Our study is not without limitations. One of the most important is related to the sample composition, as the number of male and female participants was highly unequal. This was due, mainly, to the procedure of collecting data. There is evidence that web-based studies are similar in terms of sampling with face-to-face studies (de Vaus, 2002), in our study the higher number of female participants might have biased the results as the workfamily interference is stronger for women (Amstad et al., 2011). A second limitation is given by the weak psychometric qualities of the Psychological Well Being Scale (Ryff \& Keyes, 1995). A confirmatory factorial analysis should be run on this scale on Romanian population in order to further use it with confidence in organizational studies. Thirdly, we did not include in our study any personal characteristics (such as personality factors or income) which may have an impact on satisfaction (Judge, Heller, \& Mount, 2002).

Both work to life and life to work conflict have also been associated with increased stress and burnout (Anderson et al., 2002). This aspect was not included in our study as we focused mainly on life and job satisfaction as consequences, but further studies could analyse worklife conflict as a stressor or burnout as a negative consequence of it.

Given the multidimensionality of the job satisfaction construct, a future research should use a more specific measure for it in order to assess different aspects of satisfaction, namely satisfaction with supervision and relationship with supervisor, satisfaction with the incentives and the rewards, satisfaction with work conditions etc. Self-report studies or single-survey method can also lead to biases in data collection. A combination of self-report measures with behaviour-based measures could also overcome the common-method bias.

Researchers on the topic could also pay attention to the environmental factors mediating the relationships between life and job satisfaction and to their interaction with the dispositional factors, as $\mathrm{Qu}$ and Zhao (2012) also suggested.

\section{References}

Allen, T. D., Herst, D. E., Bruck, C. S., \& Sutton, M. (2000). Consequences associated with work-to-family conflict: a review and agenda for future research. Journal of Occupational Health Psychology, 5, 278-308.

Amstad, F. T., Meier, L. L., Fasel, U., Elfering, A., \& Semmer, N. K. (2011). A meta-analysis of work-family conflict and various outcomes with a special emphasis on cross-domain versus matching-domain relations. Journal of Occupational Health Psychology, 16, 151-169.

Anderson, S. E., Coffey, B. S., \& Byerly, R. T. (2002). Formal organizational initiatives and informal workplace practices: Links to work-life conflict and job-related outcomes. Journal of Management, 28(6), 787-810.

Berkowsky, R. W. (2013). When you just cannot get away. Exploring the use of information and communication technologies in facilitating negative work/home spillover. Information, Communication \& Society, 16(4), 519-541.

Byron, K. (2005). A meta-analytic review of work-family conflict and its antecedents. Journal of Vocational Behaviour, 67(2), 169-198.

Boyne, G. A. P. (2002). Public and private management: what's the difference? Journal of Management Studies, 39(1), 97-122.

Buelens, M., \& Van den Broeck, H. (2007). An analysis of differences in work motivation between public and private organizations. Public Administration Review, 67(1), 6574.

Burke, R. J. (1997). Culture's consequences: organisational values, family-friendliness and a level playing field. Women in Management Review, 12(6), 222-227.

Burke, R. J. (2000). Do managerial men benefit from organisational values supporting work-personal life balance? Women in Management Review, 15(2), 81-89.

Cabrita, J., \& Perista, H. (2006). Measuring job satisfaction in surveys - Comparative analytical report. European Foundation for the Improvement of Living and Working Conditions.

http://www.eurofound.europa.eu/observatories/eurwork/co mparative-information/measuring-job-satisfaction-insurveys-comparative-analytical-report

Carlson, D. S., \& Kacmar, K. M. (2000). Work-family conflict in the organization: do life role values make a difference? Journal of Management, 26, 1031-1054.

Carlson D. S., Kacmar, K. M., \& Williams, L. J. (2000). Construction and initial validation of a multidimensional measure of work-family conflict. Journal of Vocational Behavior, 56, 249-276.

Cazan, A.-M. (2014). The Romanian version of the Satisfaction with Life Scale. Romanian Journal of Experimental Applied Psychology, 5(1), 42-47.

Chandra, V. (2012). Work-life balance: Eastern and western perspectives. The International Journal of Human Resource Management, 23(5), 1040-1056.

Cheung, G. W., \& Lau, R. S. (2008). Testing mediation and suppression effects of latent variables: Bootstrapping with structural equation models. Organizational Research Methods, 11(2), 296-325.

Chung, E., Kamri, T., Mathew, V. N. (2018). Work-familu conflict, work-family facilitation and job satisfaction: Considering the role of generational differences. International Journal of Education, Psychology and Counselling, 3(13), 32-43.

Cinamon, G. R. (2006). Anticipated work-family conflict: Effects of gender, self-efficacy, and family background. The Career Development Quarterly, 54, 202-215.

Connolly, J. J., \& Viswesvaran, C. (2000). The role of affectivity in job satisfaction: A meta-analysis. Personality and Individual Differences, 29, 265-281. 
DeSantis, V. S., \& Durst, S. L. (1996). Comparing job satisfaction among public-and private-sector employees. American Review of Public Administration, 26(3), 327343.

de Vaus, D. (2002). Surveys in social research, 5th ed. London: Routledge.

Diener, E., Emmons, R. A., Larsen, R. J., \& Griffin, S. (1985). The Satisfaction with Life Scale. Journal of Personality Assessment, 49, 71-75.

Dorahy, M. J., Lewis, C. A., Schumaker, J. F., AkuamoahBoateng, R., Duze, M. C., \& Sibiya, T. E. (2000). Depression and life satisfaction among Australian, Ghanaian, Nigerian, Northern Irish, and Swazi University Students. Journal of Social Behavior \& Personality, 15(4), 569-580.

Eikhof, D. R., Warhurst, C., \& Haunschild, A. (2007). Introduction: What work? What life? What balance? Critical reflections on the work-life balance debate. Employee Relations, 29(4), 325-33. doi:10.1108/01425450710839452

Gao, Y., Shi, J., Niu, Q., \& Wang, L. (2013). Work-family conflict and job satisfaction: Emotional intelligence as a moderator. Stress and Health, 29, 222-228.

Greenhaus, J. H., \& Beutell, N. J. (1985). Sources of conflict between work and family Roles. The Academy of Management Review, 10(1), 76-88.

Greenhaus, J. H., Parasuraman, S., \& Collins, K. M. (2001).Career involvement and family involvement as moderators of relationships between work-family conflict and withdrawal from a profession. Journal of Occupational Health Psychology, 6, 91-100.

Greenhaus, J. H., \& Powell, G. N. (2003). When work and family collide: Deciding between competing role demands. Organizational Behaviour and Human Decision Processes, 90, 291-303.

Grzywacz, J. G., \& Marks, N. F. (2000). Family, work, workfamily spillover, and problem drinking during midlife. Journal of Marriage and Family, 62(2), 336-348. doi: 10.1111/j.1741-3737.2000.00336.x

Golden, A. G. (2013). The structuration of information and communication technologies and work-life interrelationships: Shared organizational and family rules and resources and implications for work in a hightechnology organization. Communication Monographs, 80(1), 101-123.

Hall, D. T., Kossek, E. E., Briscoe, J. P., Pichler, S., \& Lee, M. D. (2013). Nonwork orientations relative to career: A multidimensional measure. Journal of Vocational Behavior, 83, 539-550. doi:10.1016/j.jvb.2013.07.005

Hofacker, D., \& Konig, S. (2012). Flexibility and work-life conflict in times of crisis: A gender perspective. International Journal of Sociology and Social Policy, 33(9/10), 613-635.

Hu, L. T., \& Bentler, P. M. (1999). Cutoff criteria for fit indexes in covariance structure analysis: Conventional criteria versus new alternatives. Structural Equation Modelling, 6, 1-55.

Iacobucci, D. (2008). Mediation analysis. London: Sage Publications.

Janasz, S. C., \& Behson, S. J. (2007). Cognitive capacity for processing work-family conflict: an initial examination. Career Development International, 12(4), 397-411.

Judge, T. A., Heller, D., \& Mount, M. K. (2002). Five-factor model of personality and job satisfaction: A meta-analysis. Journal of Applied Psychology, 87(3), 530 -541.

Kahn, R. L., Wolfe, D. M., Quinn, R. P., Snoek, J. D., \& Rosenthal, R. A. (1964). Organizational stress: Studies in role conflict and ambiguity. New York: Wiley.

Keyes, C. L. M., Ryff, C. D., \& Schmotkin, D. (2002). Optimizing well-being: The empirical encounter of two traditions. Journal of Personality and Social Psychology, 82, 1007-1022.

Kossek, E. E., \& Ozeki, C. (1998). Work-family conflict, policies, and the job-life satisfaction relationship: a review and directions for organizational-human resources research. The Journal of Applied Psychology, 83, 139-49.

Lyness, K. S., \& Thompson, D. E. (1997). Above the Glass Ceiling? A Comparison of Matched Samples of Female and Male Executives. Journal of Applied Psychology, 82, 359-375. https://doi.org/10.1037/0021-9010.82.3.359

Markovits, Y., Davis, A., Fay, D., \& van Dick, R. (2010). The link between job satisfaction and organizational commitment: Differences between public and private sector employees. International Public Management Journal, 13(2), 177-196.

McMillan, H. S., \& Morris, M. L. (2012). Examining the relationship between work/life conflict and life satisfaction in executives: The importance of problem-solving coping interventions and HRD. Advances in Developing Human Resources, 14(4), 640-663.

McShane, S. L., \& Von Glinow, M. A. (2012). Organizational behaviour. Boston: Irwin/McGraw-Hill.

Michaels, R. E., Cron, W. L., Dubinsky, A. J., \& Joachimsthaler, E. A. (1988). Influence of formalization on the organizational commitment and work alienation of sales people and industrial buyers. Journal of Marketing Research, 25, 376-383.

Minnotte, K. L., Gravelle, M., \& Minnotte, M. C. (2013). Workplace characteristics, work-to-life conflict, and psychological distress among medical workers. The Social Science Journal, 50(4), 408-417.

Netemeyer, R. G, Boles, J. S., \& McMurrian, R. C. (1996). Development and validation of Work-Family Conflict and Family-Work Conflict Scales. Journal of Applied Psychology, 81, 400-410.

Neto, M., Chambel, M. J., \& Carvalho, V. S. (2018). Workfamily life conflict and mental well-being. Occupational Medicine, 68(6), 364-369. doi:10.1093/occmed/kqy079

Qu, H., \& Zhao, X. R. (2012). Employees' work-family conflict moderating life and job satisfaction. Journal of Business Research, 65, 22-28.

Rask, K., Astedt-Kurki, P., \& Laippala, P. (2002). Adolescent subjective well-being and realized values. Journal of Advanced Nursing, 38(3), 254-263.

Rioux, L. (2006). Construction d'une échelle d'attachement au lieu de travail. Une démarche exploratoire [Construction of a workplace attachment scale. An exploratory research]. Canadian Journal of Behaviour Science, 38(4), 325-336.

Rioux, L., \& Pignault, A. (2013). Workplace attachment, workspace appropriation, and job satisfaction. Bilingual Journal of Environmental Psychology, 4(1), 39-65.

Roehling, P., Moen, P., \& Batt, R. (2003). Spillover. In P. Moen (Ed.), It's about time: Couples and careers (pp. 101-121). Ithaca, NY: Cornell University Press.

Ryff, C. D. (1989). Happiness is everything, or is it? Explorations on the meaning of psychological well-being. Journal of Personality and Social Psychology, 57(6), 1069-1081.

Ryff, C. D., \& Keyes, C. L. M. (1995). The structure of psychological well-being revisited. Journal of Personality and Social Psychology, 69, 719-727.

Sirgy, M. J., \& Lee, D.-J. (2018). Work-life balance: An integrative review. Applied Research in Quality of Life, 13, 229-254. DOI 10.1007/s11482-017-9509-8

Spector, P. E. (1997). Job satisfaction: Application, assessment, causes, and consequences. United Kingdom: Sage Publications Ltd.

Spector, P. E. (1985). Measurement of human service staff satisfaction: Development of the job satisfaction survey. American Journal of Community Psychology, 13, 693-713. 
Spector, P. E., Allen, T. D., Poelmans, S., Lapierre, L. M., Cooper, C. L., O'Driscoll, M., Sanchez, J. I., Abarca, N., Alexandrova, M., Beham, B., Brough, P., Ferreiro, P., Fraile, G., Lu, C., Lu, L., Moreno-Velázquez, I., Pagon, M., Pitariu, H., Salamatov, V., Shima, S., Suarez Simoni, A., Siu, O. L., \& Widerszal-Bazyl, M. (2007). Crossnational differences in relationships of work demands, job satisfaction and turnover intentions with work-family conflict. Personnel Psychology, 60, 805-835.

Wang, Y. D., Yang, C., \& Wang, K. Y. (2012). Comparing public and private employees' job satisfaction and turnover. Public Personnel Management, 41(3), 557-573.
Watson, D., Clark, L. A., \& Tellegen, A. (1988). Development and validation of brief measures of positive and negative affect: The PANAS scales. Journal of Personality and Social Psychology, 54(6), 1063-1070.

Zedeck, S. (1992). Work, families, and organizations. San Francisco: Jossey-Bass.

***World Economic Forum (2018). The global gender gap report 2018.

http://www3.weforum.org/docs/WEF_GGGR 2018.pdf 